\title{
Morphological modification by tubercle bacilli: no time for denial
}

\author{
Ali Akbar Velayati ${ }^{1}$, Parissa Farnia ${ }^{1,2}$, Mohammad Reza Masjedi ${ }^{1}$, Gennady Konstantinovich \\ Zhavnerko ${ }^{2,3}$, Jalaledin Ghanavi ${ }^{4}$, Nikolai Nikolaevich Poleschuyk ${ }^{2}$ \\ ${ }^{1}$ Mycobacteriology Research Centre(MRC), National Research Institute of Tuberculosis and Lung Disease \\ (NRITLD), WHO; UNION Collaborating Centre for TB and Lung Diseases, Shahid Beheshti University (Medical \\ Campus), Darabad, Tehran, Iran. \\ ${ }^{2}$ The Republican Research and Practical Centre for Epidemiology and Microbiology, Minsk, Belarus. \\ ${ }^{3}$ Institute for Chemistry of New Materials, Belarus National Academy of Sciences, Minsk, Belarus. \\ ${ }^{4}$ Experimental \& animal research Laboratory, NRITLD, Shahid Beheshti University (Medical Campus), Darabad, \\ Tehran, Iran
}

Key words: M. tuberculosis; morphology. XXDR-TB; latent TB

J Infect Dev Ctries 2012; 6(1):97-99.

(Received 22 August 2011 - Accepted 25 August 2011)

Copyright () 2012 Velayati et al. This is an open-access article distributed under the Creative Commons Attribution License, which permits unrestricted use, distribution, and reproduction in any medium, provided the original work is properly cited.

To be very honest, few people care about bacterial morphology. This is very unfortunate, because the subject of morphology addresses a fundamental biological question, the significance of which has been decided by the organisms themselves. A simple way to verify this is to take a look at the cultures of $M$. tuberculosis under different condition inside and outside the host [1]. They become shorter in older cultures, filamentous within macrophages, and ovoid during starvation $[2,3]$. These morphological changes are examples in which cell shape is implicated but not yet proven to be important. Based on World Health Organization (WHO) data, there are 8 million active cases of tuberculosis (TB) with 3 million deaths per year. In addition, about one third of the global population is estimated to suffer from latent tuberculosis [4]. This high number of cases may not only reflect the poor implementation of TB control programs, but it may also represent our failure to understand the basic biology of M. tuberculosis.

We recently demonstrated the morphological changes in extremely drug-resistant (XXDR) tuberculosis strains $[5,6,7]$. The XXDR-TB strains showed in vitro resistance to all first- and secondline drugs tested [8,9]. Under atomic force microscopy, $30 \%$ of the XXDR-TB cells had an oval- or round-shaped appearance [5,6]. In this context, Champion and Mitragotri highlighted the importance of morphology with regard to the immune system [10]. Those authors created microscopic polystyrene particles of six different shapes in various size, fed them to alveolar macrophages, and found that shape, not size, was the dominant factor in determining whether particles were phagocytized [10]. Thereby, morphological alterations in XXDR-TB strains, could explain the enhanced ability of bacilli to escape immune responses [7]. At present, the numbers of patients infected with XXDR-TB strains are low, but the main problem is how to cure and control such cases without effective antibiotics and new preventive strategies, respectively. More recently, we studied the anaerobic culture of $M$. tuberculosis as a model of latency [11]. For the first time, the sequential changes in tubercle bacilli $\left(\mathrm{H}_{37} \mathrm{RV}\right)$ from one month to 48 months of latency were documented. The latent $\mathrm{TB}$ bacilli transformed themselves from classical rod-shaped, acid-fast cells (1.5 to $3.0 \mu \mathrm{m}$ size) into oval and non acid-fast forms ( 0.1 to $0.3 \mu \mathrm{m})$. These cells were metabolically active and they could recover their original biological properties when they transferred into a favorable environment (mice model). Therefore, TB bacilli can adapt and survive in any hostile environment by changing its morphology (Figures 1 and 2).

In conclusion, shape of bacilli can be seen as a marker of virulence, of biological defense against 
Figure 1. Laboratory strains of M. tuberculosis (H37RV) at exponential phase of growth. Viewed under atomic force microscopy (AFM)

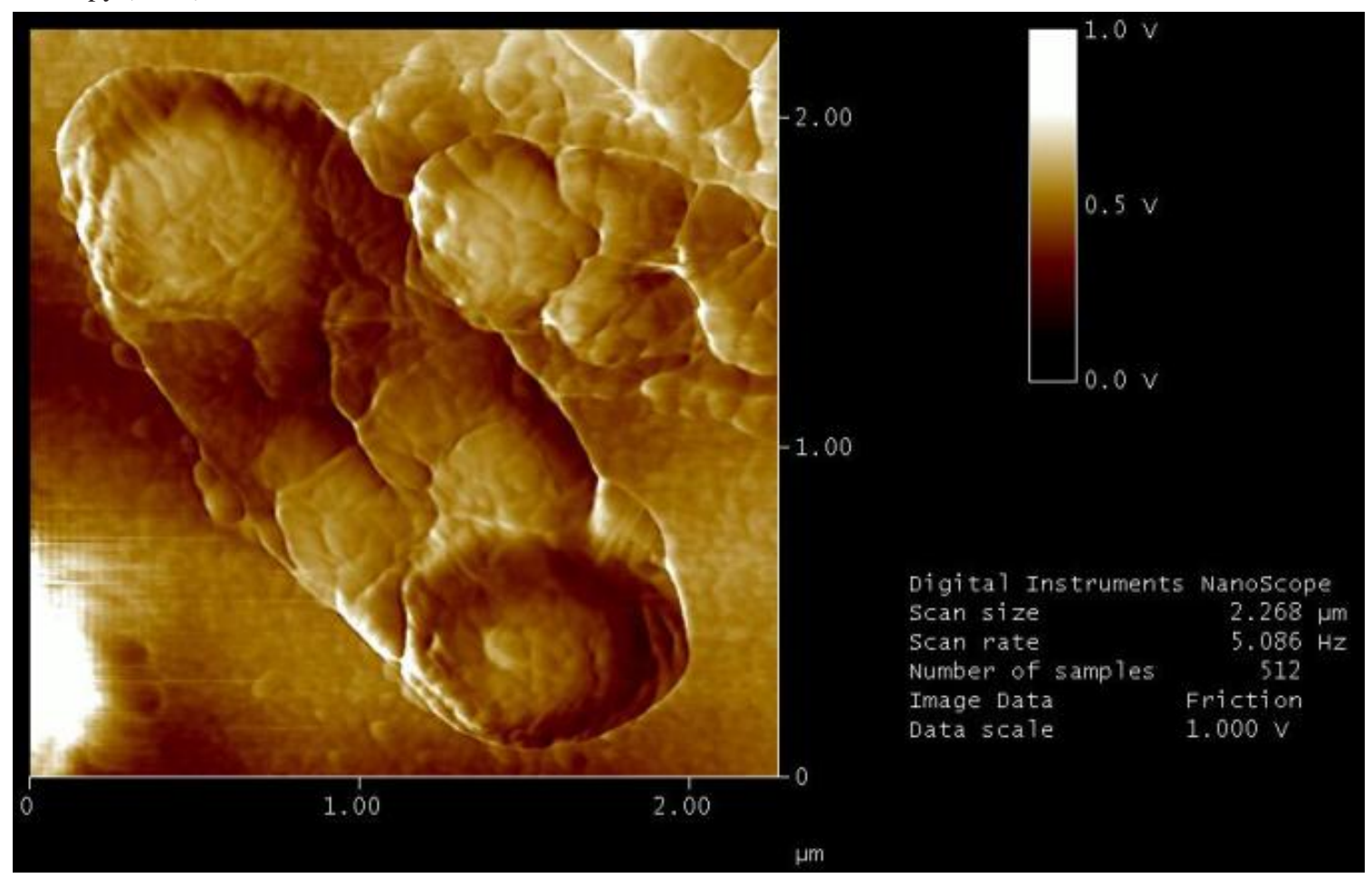

Figure 2. Latent M. tuberculosis (H37RV) after 36 months of anaerobic culture. The latent TB bacilli are ovoid and are non acid-fast forms $(0.1$ to $0.3 \mu \mathrm{m})$

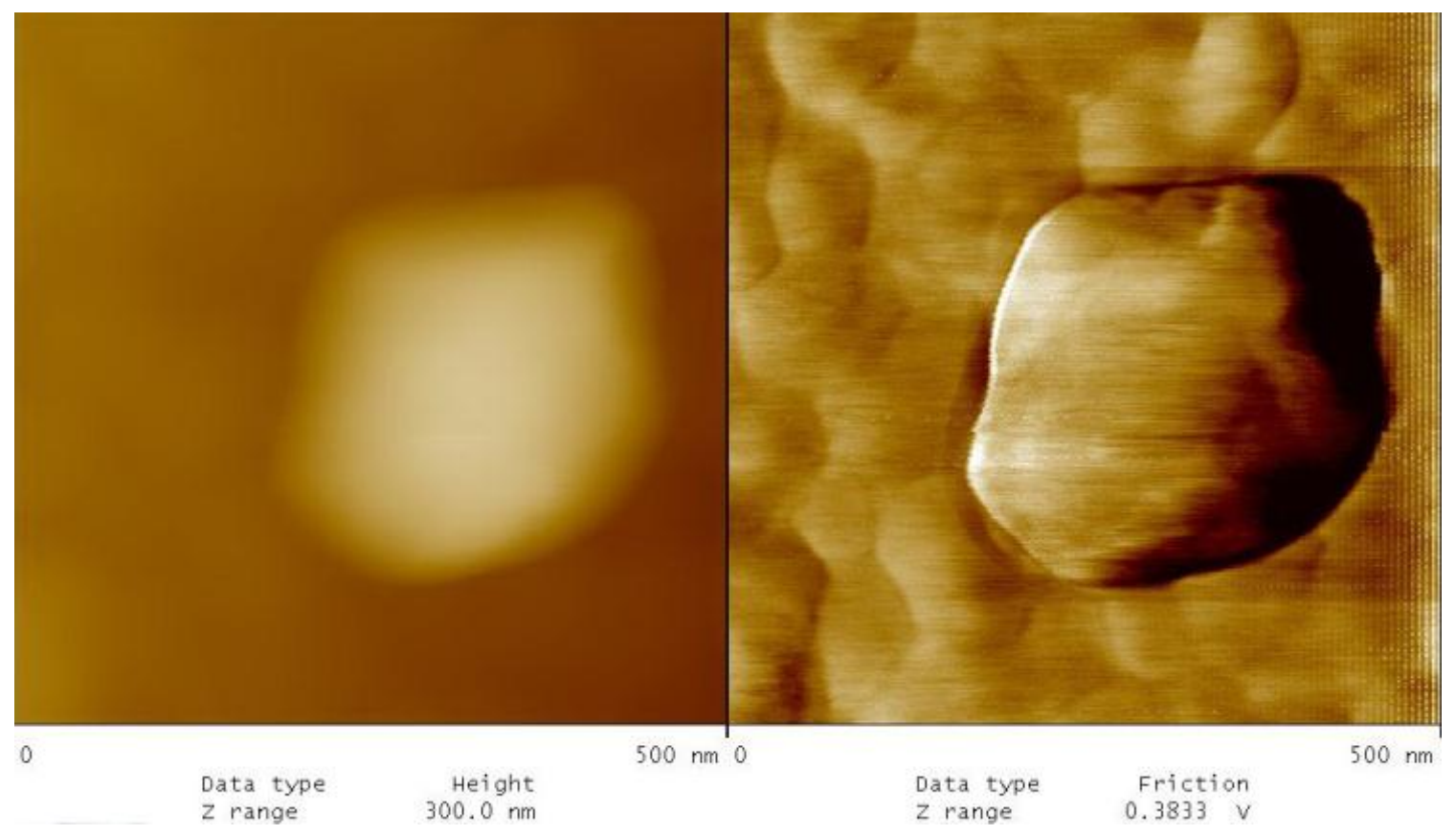


specific immune responses, or of cell division. Today, most of investigators agree that the Koch bacillus does not always manifest itself in the classical rod shape. However, the possible significance of such variant forms with respect to etiology, control, and prognosis of tuberculosis infection are not very clear. Hence the efforts to design new strategies and innovative approaches should target these uncharacterized cell populations of $M$. tuberculosis also. This is an urgent issue that needs support from the global scientific community.

\section{Acknowledgments}

The authors wish to thank the staff of the Microbiology Unit at the Republican Research and practical Centre for Epidemiology and Microbiology (Minsk, Belarus).

\section{References}

1. Cardona PJ and Manzano JR (2004) On the nature of Mycobacterium tuberculosis-latent bacilli. Eur Respir J 24: 1044-1051.

2. Wayne LG (1994) Dormancy of M. tuberculosis and latency of disease. Eur J Clin Microbiol Infect Dis 13: 908-914.

3. Shleeva MO, Kudykina YK, Vostroknutova GN, Suzina NE, Mulyukin AL, Kapresyants AS (2011) Dormant ovoid cells of Mycobacterium tuberculosis are formed in response to gradual external acidification. Tuberculosis (Edinb) 91: 146154.

4. World Health Organization. Global tuberculosis control. WHO report 2001(WHO/CDS/TB/2001.287). Geneva. World Health Organization http;//whqlibdoc.who.int/hq/2001/WHO_CDS_TB_2001.287.

5. Velayati AA, Farnia P, Masjedi MR, Ibrahim TA, Tabarsi P, Haroun RZ, Kuan HO, Ghanavi J, Farnia P, Varahram M (2009) Totally drug resistant tuberculosis strains: evidence of adaptation at the cellular level. Eur Respir J 34: 1-3.

6. Velayati AA, Farnia P, Merza MA, Zhavnerko GK, Tabarsi P, Titov LP, Ghanavei J, Farnia P, Setare M, Poleschuyk NN, Owlia P, Sheikolslami M, Ranjbar R, Masjedi MR (2010)
New insight into extremely drug-resistant tuberculosis: using atomic force microscopy. Eur Respir J 36: 1490-1493.

7. Farnia P, Masjedi MR, Farnia P, Merza MA, Tabarsi P, Zhavnerko GK, Ibrahim TA, Kuan HO, Ghanavei J, Farnia P, Ranjbar R, Poleschuyk NN, Titov LP, Owlia P, Kazampour M, Setareh M, Sheikolslami M, Migliori GB, Velayati AA (2010) Growth and cell-division in extensive (XDR) and extremely drug resistant (XXDR)tuberculosis strains: transmission and atomic force observation. Int J Clin Exp Med 3: 320-326.

8. Velayati AA, Masjedi MR, FarniaP, Tabarsi P, Ghanavi J, Ziazarifi AH, Hoffner SE (2009) Emergence of new forms of totally drug resistant tuberculosis bacilli: super extensively drug resistant tuberculosis or totally drug-resistant strains in Iran. Chest 136: 420-425.

9. Milgliori GB, De Iaco G, Besozzi G, Centis R, Cirill DM (2007) First tuberculosis cases in Italy resistant to all tested drugs.Eurosurveillance Weekly Release.12: 3194.

http://www.eurosurveillance.org/aspx/ArticleId-3194

10. Champion JA and Mitragotri S (2006) Role of target geometry in phagocytosis. Proc Natl Acad Sci USA 103:4930-4934.

11. Velayati AA, Farnia P, Masjedi MR, Zhavnerko GK,Merza AM, Tabarsi P, Farnia P, Poleschuyk NN, Ignatyev G.(2011) Sequential Adaptation in Latent Tuberculosis Bacilli: observation by atomic force microscopy (AFM). Int $\mathrm{J}$ Clin Exp Med (In press).

\section{Corresponding author}

Parissa. Farnia

Mycobacteriology Research Centre

NRITLD/UNION \& WHO Collaborative Centre for TB \& Lung

Diseases

Shahid Beheshti University (Medical Campus)

Tehran 19556

PO Box 19575/154

Iran

Fax No: 00982120109505

Email: pfarnia@hotmail.com, Pfarnia@theaasm.org

Conflict of interests: No conflict of interests is declared. 